\title{
Human papillomavirus prevalence in South African women and men according to age and human immunodeficiency virus status
}

\author{
Zizipho Z A Mbulawa ${ }^{1,2}$, David Coetzee ${ }^{3}$ and Anna-Lise Williamson ${ }^{1,4,5^{*}}$
}

\begin{abstract}
Background: Both cervical cancer and human immunodeficiency virus (HIV) are major public health problems in Sub-Saharan Africa. The objectives of the study were to investigate human papillomavirus (HPV) prevalence according to age, HIV status and gender.

Methods: Participants were 208 HIV-negative women, 278 HIV-positive women, 325 HIV-negative men and 161 HIV-positive men between the ages of 18-66 years. HPV types were determined in cervical and penile cells by Roche Linear Array HPV genotyping assay.

Results: HPV prevalence was 36.7 \% (76/207; 95 \% confidence intervals (CI): 30.4-43.4 \%) in HIV-negative women, with the highest prevalence of $61.0 \%(25 / 41 ; 95 \% \mathrm{Cl}: 45.7-74.4 \%)$ in women aged $18-25$ years. HPV prevalence was $74.0 \%$ (205/277; $95 \%$ Cl: 68.5-78.8\%) in HIV-positive women, with the highest prevalence of $86.4 \%$ (38/44; $95 \% \mathrm{Cl}$ : 72.9-94.0\%) in women aged 18-25 years. HPV prevalence was found to decrease with increasing age in HIV-negative women ( $P=0.0007)$, but not in HIV-positive women $(P=0.898)$. HPV prevalence was $50.8 \%$ (159/313; $95 \%$ Cl: 45.3-56.3\%) in HIV-negative men, with the highest prevalence of $77.0 \%$ (27/35; $95 \%$ Cl: 60.7-88.2 \%) in men aged 18-25 years. HPV prevalence was $76.6 \%$ (121/158; 95 \% Cl: 69.2-82.9\%) in HIV-positive men, with the highest prevalence of $87.5 \%(7 / 8 ; 95 \% \mathrm{Cl}$ : 50.8-99.9\%) in men 18-25 years of age. HPV prevalence was found to decrease with increasing age in HIV-negative men $(P=0.004)$, but not in HIV-positive men $(P=0.385)$. HIV-positive women had a significantly higher prevalence of one or more HPV type(s) in the bivalent (HPV-16/18: 20 \% 55/277, 9 \% 12/207; P <0.001), quadrivalent (HPV-6/11/16/18: 26 \% 71/277, 12 \% 24/207; $P=0.001$ ) and nonavalent vaccine (HPV-6/11/16/18/31/33/52/56/58: $65 \%$ 181/277, $24 \%$ 50/207; $P<0.001$ ) compared to HIV-negative women. Similar observation were observed in men for bivalent $(20 \% 32 / 158,10 \% 30 / 313 ; P=0.001)$, quadrivalent ( $35 \%$ 56/158, $13 \%$ 41/313; $P<0.001$ ) and nonavalent vaccine (75 \% 119/158, $28 \%$ 87/313; $P<0.001)$.
\end{abstract}

Conclusions: This study demonstrated high HPV prevalence among HIV-positive women and men in all age groups. The high prevalence of HPV types found in bivalent, quadrivalent and nonavalent vaccines in South African HIV-positive and HIV-negative women and men demonstrate that this population will greatly benefit from current HPV vaccines.

Keywords: Human papillomavirus, Human immunodeficiency virus, Age

\footnotetext{
* Correspondence: Anna-Lise.Williamson@uct.ac.za

${ }^{1}$ Institute of Infectious Disease and Molecular Medicine and Division of

Medical Virology, University of Cape Town, Anzio Road, Observatory, 7925

Cape Town, South Africa

${ }^{4}$ SAMRC Gynaecological Cancer Centre, University of Cape Town, Cape Town,

South Africa

Full list of author information is available at the end of the article
}

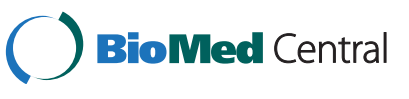

(c) 2015 Mbulawa et al. Open Access This article is distributed under the terms of the Creative Commons Attribution 4.0 International License (http://creativecommons.org/licenses/by/4.0/), which permits unrestricted use, distribution, and reproduction in any medium, provided you give appropriate credit to the original author(s) and the source, provide a link to the Creative Commons license, and indicate if changes were made. The Creative Commons Public Domain Dedication waiver (http://creativecommons.org/publicdomain/zero/1.0/) applies to the data made available in this article, unless otherwise stated. 


\section{Background}

Worldwide 35.3 million people were living with human immunodeficiency virus (HIV) in 2012; 25 million in sub-Saharan Africa and 6.3 million in South Africa $[1,2]$. HIV prevalence is higher in women than men. The peak in women is between 25 and 29 years while in men it is between 30 and 34 years of age [1-3]. In South Africa, women are more likely to have sexual partners who are 4 years older than themselves [4-7]. The median age at first sex in South African women ranges between 16 and 18 years while in men it ranges between 17 and 19 years of age $[6,8]$. In a worldwide meta-analysis Africa was found to have the highest human papillomavirus (HPV) prevalence in women with normal cytology $[9,10]$. Sub-Saharan Africa has the highest burden of HIV and cervical cancer and the epidemic of cervical cancer and HIV infection are major public health problems $[2,11]$.

Both HIV and HPV are sexually transmitted, with HPV being more infectious than HIV [12]. The prevalence of HIV and HPV is significantly higher among women and men with high-risk sexual behaviour [10]. HIV infection is significantly associated with a higher incidence of HPV, prevalence of HPV and persistence in women and men [13-15]. HIV-positive individuals are more likely to have multiple HPV infection and HPV viral load compared to their HIV-negative counterparts [16-19]. HPV-associated cancers occur more frequently in HIV-positive than in HIV-negative individuals $[20,21]$. There is increasing evidence that HPV is associated with a two-three fold higher risk of HIV acquisition in both women and men [12, 22-30]. There are three HPV vaccines available, namely, bivalent vaccine (Cervarix ${ }^{\circ}$, GlaxoSmithKline) protecting against HPV $16 / 18$, quadrivalent vaccine (Gardasil ${ }^{\circ}$, Merck), protecting against HPV 6/11/16/18 and nonavalent vaccine (Merck) protecting against HPV-6/11/16/18/31/33/52/56/58). These vaccines prevent infection and disease related to types they are targeting [31-36]. In March 2014, South Africa introduced vaccination with Cervarix against HPV in schools, aiming to cover around 520000 girls.

HPV prevalence decreases with increasing age in women $[9,37]$. However, among older women inconsistent trends in HPV prevalence are observed, with some studies reporting a decrease or plateau in HPV prevalence while others report an increased HPV prevalence in older women [37]. HPV prevalence in women differs by country, region within the country and population group and this is likely to be due to the varying prevalence of high risk sexual behaviour worldwide [38]. HPV is acquired soon after sexual debut and the peak prevalence is observed in young women. The age distribution of HPV prevalence in African women is characterised by a U shape with high HPV prevalence in young and older ages $[9,38]$. In sub-Saharan Africa genital HPV is reported to be very common in men $[39,40]$ and HPV prevalence does not decrease with age [41, 42]. The aim of this study is to demonstrate HPV prevalence, stratified by age and HIV status in women and men recruited from the same community.

\section{Methods}

\section{Study population and specimen collection}

The Research Ethics Committee of the University of Cape Town approved the study (reference: 258/2006) and written informed consent was obtained. Study participants were recruited from the Manyanani clinic, Empilisweni Centre, Gugulethu, Cape Town, South Africa between 2006 and 2009. Empilisweni is a wellness centre where HIV-related research is conducted. Individuals were recruited through clinics, bus stops and taxi ranks and eligible individuals were asked to come to Manyanani clinic. The study participants had to have had penetrative sexual intercourse with the partner of the opposite sex in the previous month to be enrolled in the study. Participation to the study was completely voluntary.

Cervical samples were collected by clinician using Digene cervical samplers. Clinicians collected penile samples by swabbing the penile shaft, glans, and foreskin with a dry Digene swab. Genital samples were stored in Digene transport medium at $-80{ }^{\circ} \mathrm{C}$ until analysed. Study participants included 208 HIV-negative women, 278 HIV-positive women, 325 HIV-negative men and 161 HIV-positive men between the ages of 18 and 66 years. Cervical and penile samples were collected and stored as described by Mbulawa et al., [43].

\section{HPV genotyping}

DNA was extracted by a MagNA Pure Compact (Roche) using the MagNA Pure Compact Nucleic Acid Isolation Kit (Roche). HPV genotyping was performed using the Roche Linear Array HPV genotyping test which identifies 37 different HPV genotypes. High-risk (HR) HPV types included HPV $-16,-18,-31,-33,-35,-39,-45$, $-51,-52,-56,-58$ and -59 ; probably or possible HRHPV types included HPV-26, -53, -66, -67, -68, -70, -73 and -82 ; and low-risk (LR) HPV types HPV-6, -11 , $-40,42,-54,-55,-61,-62,-64,-69,-71,-72,-81$, $-83,-84,-89$ (HPV-CP6108) and -IS39 [44].

\section{Statistical analyses}

Multiple HPV infection was defined as infection where two or more HPV types were detected. Cases with multiple infections were counted more than once when determining LR-HPV, HR-HPV, bivalent, quadrivalent or nonavalent prevalence. Statistical analysis was performed using chi-squared and chi-squared for trends (GraphPad prism 5). The $95 \%$ confidence intervals of the 
proportion were calculated by modified Wald method (GraphPad Prism). Differences were considered to be statistically significant when $P$-values were $<0.05$.

\section{Results}

HPV prevalence in women according to age and HIV status Demographic data are presented in Table 1. The median age was 37 years (18-66 years) for HIV-negative women; 32 years (18-65 years) for HIV-positive women; 38 years (19-67 years) for HIV-negative men and 36 years (2264 years) for HIV-positive men. Table 2 presents the prevalence of any HPV, HR-HPV, probable HR-HPV, LR-HPV, multiple HPV infection and single HPV infection stratified by age and HIV status in women. Overall
HPV prevalence in women was $58.1 \%(281 / 484 ; 95 \%$ CI: $53.6-62.4 \%)$, with the highest prevalence of $74.1 \%$ (63/85; 95 \% CI: 63.9-82.3\%) observed in women 18-25 years of age and lowest prevalence of $50.0 \%(67 / 134$; 95 \% CI: 41.7-58.4 \%) in women 36-45 years of age. Age group 18-25 years were found to have significantly higher HPV prevalence compared to 26-35 years (74.1 \% compared to $59.0 \%, P=0.017$ ); to $36-45$ years (74.1\% compared to $50.0 \%, P=0.0004$ ) and to $46-66$ years $(74.1 \%$ compared to $51.9 \%, P=0.0035)$. HPV prevalence was found to decrease with increasing age in women $(P=0.0032)$. The prevalence of multiple infections was $34.3 \%(166 / 484)$ and of single infection was 23.8 \% (115/484; Table 2).

Table 1 The demographic data of study participants

\begin{tabular}{|c|c|c|c|c|}
\hline & HIV-negative women, $N=208$ & HIV-positive women, $N=278$ & HIV-negative men, $N=325$ & HIV-positive men, $N=161$ \\
\hline Median age (range) & 37 years (18-66 years) & 32 years (18-65 years) & 38 years (19-67 years) & 36 years (22-64 years) \\
\hline $18-25$ years & $N=41$, median: 22 years & $N=44$, median: 23 years & $N=35$, median: 24 years & $N=8$, median: 23 years \\
\hline $26-35$ years & $N=59$, median: 30 years & $N=130$, median: 30 years & $N=99$, median: 31 years & $N=64$, median: 31 years \\
\hline $36-45$ years & $N=64$, median: 40 years & $N=71$, median: 39 years & $N=105$, median: 40 years & $N=67$, median: 39 years \\
\hline $46-66$ years & $N=44$, median: 49 years & $N=33$, median: 49 years & $N=86$, median: 53 years & $N=22$, median: 52 years \\
\hline \multicolumn{5}{|l|}{ CD4 count } \\
\hline$\geq 350 \mathrm{ml}^{-1}$ & .. & $139(50 \%)$ & .. & $76(47.2 \%)$ \\
\hline$<350 \mathrm{ml}^{-1}$ & .. & $137(49.3 \%)$ & .. & $81(50.3 \%)$ \\
\hline Missing & .. & $2(0.7 \%)$ & .. & $4(2.5 \%)$ \\
\hline \multicolumn{5}{|l|}{ Age at first sex } \\
\hline$<16$ years & $28(63.9 \%)$ & 49 (17.6\%) & 87 (26.8 \%) & $40(24.8 \%)$ \\
\hline 16-18 years & $123(59.1 \%)$ & $171(61.5 \%)$ & $163(50.2 \%)$ & $94(58.4 \%)$ \\
\hline$>18$ years & $55(26.4 \%)$ & $57(20.5 \%)$ & $71(21.8 \%)$ & $26(16.2 \%)$ \\
\hline Missing & $2(1.0 \%)$ & $1(0.4 \%)$ & $4(1.2 \%)$ & $1(0.6 \%)$ \\
\hline \multicolumn{5}{|l|}{ Smoking } \\
\hline Never & $133(63.9 \%)$ & $182(65.5 \%)$ & $48(26.8 \%)$ & $31(19.3 \%)$ \\
\hline Previously & $13(6.3 \%)$ & $28(10.1 \%)$ & $45(13.8 \%)$ & $26(16.1 \%)$ \\
\hline Current & $62(29.8 \%)$ & $68(24.5 \%)$ & $228(70.2 \%)$ & $104(64.6 \%)$ \\
\hline Missing & $0(0.0 \%)$ & $0(0.0 \%)$ & $4(1.2 \%)$ & $0(0 \%)$ \\
\hline \multicolumn{5}{|c|}{ Lifetime number of sexual partners } \\
\hline $1-3$ & $137(65.9 \%)$ & $134(48.2 \%)$ & 94 (28.9 \%) & $39(24.2 \%)$ \\
\hline $4-6$ & $51(24.5 \%)$ & $106(38.1 \%)$ & $91(28.0 \%)$ & $38(23.6 \%)$ \\
\hline$\geq 7$ & $17(8.2 \%)$ & $37(13.3 \%)$ & $136(41.8 \%)$ & $82(50.9 \%)$ \\
\hline Missing & $3(1.4 \%)$ & $1(0.4 \%)$ & $4(1.2 \%)$ & $2(1.2 \%)$ \\
\hline \multicolumn{5}{|l|}{ Cervical cytology } \\
\hline Normal & $157(75.5 \%)$ & $167(60.1 \%)$ & & \\
\hline ASCUS & 19 (9.1\%) & $23(8.3 \%)$ & & \\
\hline LSIL & $17(8.2 \%)$ & $63(22.7 \%)$ & & \\
\hline $\mathrm{HSIL}$ & $2(1.0 \%)$ & $10(3.6 \%)$ & & \\
\hline Inadequate & $13(6.2 \%)$ & $14(5.0 \%)$ & & \\
\hline Missing & $0(0.0 \%)$ & $1(0.4 \%)$ & & \\
\hline
\end{tabular}


Table 2 Human papillomavirus (HPV) by age and human immunodeficiency (HIV) status in women

\begin{tabular}{|c|c|c|c|c|}
\hline & All women & HIV-positive women & HIV-negative women & $P$-value ${ }^{a}$ \\
\hline & $N=484$ & $N=277$ & $N=207$ & \\
\hline Any HPV & & & & \\
\hline All women & $58.1 \%(281 / 484)$ & $74.0 \%(205 / 277)$ & $36.7 \%(76 / 207)$ & $<0.0001$ \\
\hline $18-25$ years & $74.1 \%(63 / 85)$ & $86.4 \%(38 / 44)$ & $61.0 \%(25 / 41)$ & 0.008 \\
\hline $26-35$ years & $59.0 \%(111 / 188)$ & $68.2 \%(88 / 129)$ & $39.0 \%(23 / 59)$ & 0.0002 \\
\hline $36-45$ years & $50.0 \%(67 / 134)$ & $73.2 \%(52 / 71)$ & $23.8 \%(15 / 63)$ & $<0.0001$ \\
\hline $46-66$ years & $51.9 \%(40 / 77)$ & $81.8 \%(27 / 33)$ & $29.5 \%(13 / 44)$ & $<0.0001$ \\
\hline Multiple HPV infec & & & & \\
\hline All women & $34.3 \%(166 / 484)$ & $49.8 \%(138 / 277)$ & $13.5 \%(28 / 207)$ & $<0.0001$ \\
\hline $18-25$ years & $47.1 \%(40 / 85)$ & $61.4 \%(27 / 44)$ & $31.7 \%(13 / 41)$ & 0.007 \\
\hline $26-35$ years & $34.6 \%(65 / 188)$ & $45.0 \%(58 / 129)$ & $11.9 \%(7 / 59)$ & $<0.0001$ \\
\hline $36-45$ years & $30.6 \%(41 / 134)$ & $49.3 \%(35 / 71)$ & $9.5 \%(6 / 63)$ & $<0.0001$ \\
\hline $46-66$ years & $26.0 \%(20 / 77)$ & $54.5 \%(18 / 33)$ & $4.5 \%(2 / 44)$ & $<0.0001$ \\
\hline Single HPV infectic & & & & \\
\hline All women & $23.8 \%(115 / 484)$ & $24.2 \%(67 / 277)$ & $23.2 \%(48 / 207)$ & 0.800 \\
\hline $18-25$ years & $27.1 \%(23 / 85)$ & $25.0 \%(11 / 44)$ & $29.3 \%(12 / 41)$ & 0.664 \\
\hline $26-35$ years & $24.5 \%(46 / 188)$ & $23.3 \%(30 / 129)$ & $27.1 \%(16 / 59)$ & 0.570 \\
\hline $36-45$ years & $19.4 \%(26 / 134)$ & $23.9 \%(17 / 71)$ & $14.3 \%(9 / 63)$ & 0.161 \\
\hline $46-66$ years & $26.0 \%(20 / 77)$ & $27.3 \%(9 / 33)$ & $25.0 \%(11 / 44)$ & 0.828 \\
\hline HR-HPV & & & & \\
\hline All women & $39.5 \%(191 / 484)$ & $52.0 \%(144 / 277)$ & $22.7 \%(47 / 207)$ & $<0.0001$ \\
\hline $18-25$ years & $54.1 \%(46 / 85)$ & $72.7 \%(32 / 44)$ & $34.1 \%(14 / 41)$ & 0.0004 \\
\hline $26-35$ years & $37.2 \%$ (70/188) & $40.3 \%(52 / 129)$ & $30.5 \%(18 / 59)$ & 0.199 \\
\hline $36-45$ years & $41.8 \%(56 / 134)$ & $64.8 \%(46 / 71)$ & $15.9 \%(10 / 63)$ & $<0.0001$ \\
\hline $46-66$ years & $24.7 \%(19 / 77)$ & $42.4 \%(14 / 33)$ & $11.4 \%(5 / 44)$ & 0.002 \\
\hline Probable HR-HPV & & & & \\
\hline All women & $21.1 \%(102 / 484)$ & $30.7 \%(85 / 277)$ & $8.2 \%(17 / 207)$ & $<0.0001$ \\
\hline $18-25$ years & $25.9 \%(22 / 85)$ & $34.1 \%(15 / 44)$ & $17.1 \%(7 / 41)$ & 0.080 \\
\hline $26-35$ years & $27.1 \%(51 / 188)$ & $37.2 \%(48 / 129)$ & $5.1 \%(3 / 59)$ & $<0.0001$ \\
\hline $36-45$ years & $15.7 \%(21 / 134)$ & $22.5 \%(16 / 71)$ & $7.9 \%(5 / 63)$ & 0.02 \\
\hline $46-66$ years & $10.4 \%(8 / 77)$ & $18.2 \%(6 / 33)$ & $4.5 \%(2 / 44)$ & 0.055 \\
\hline LR-HPV & & & & \\
\hline All women & $34.5 \%(167 / 484)$ & $49.8 \%(138 / 277)$ & $14.0 \%(29 / 207)$ & $<0.0001$ \\
\hline $18-25$ years & $44.7 \%(38 / 85)$ & $63.6 \%(28 / 44)$ & $24.4 \%(10 / 41)$ & 0.0003 \\
\hline $26-35$ years & $36.7 \%$ (69/188) & $48.1 \%(62 / 129)$ & $11.9 \%(7 / 59)$ & $<0.0001$ \\
\hline $36-45$ years & $26.9 \%(36 / 134)$ & $43.7 \%(31 / 71)$ & $7.9 \%(5 / 63)$ & $<0.0001$ \\
\hline $46-66$ years & $31.2 \%(24 / 77)$ & $51.5 \%(17 / 33)$ & $15.9 \%(7 / 44)$ & 0.0006 \\
\hline
\end{tabular}

Number of infection will not always add up because participants with multiple infection were sometimes counted more than once. ${ }^{\mathrm{a}}$ compares HIV-positive and HIV-negative women (chi-squared test)

HPV prevalence was 74.0 \% (205/277; 95 \% CI: $68.5-$ $78.8 \%$ ) in HIV-positive women, with the highest prevalence of $86.4 \%$ (38/44; $95 \%$ CI: 72.9-94.0\%) in women $18-25$ years of age and lowest prevalence of $68.2 \%(88 /$ 129; 95 \% CI: 60.0-75.6 \%) in women 26-35 years of age. HIV-positive age group 18-25 years were found to have significantly higher HPV prevalence compared to 26-35 years $(86.4 \%$ compared to $68.2 \%, P=0.02)$; but not $36-$ 45 years $(86.4 \%$ compared to $73.2 \%, P=0.1)$ and $46-66$ years age group (86.4 \% compared to $81.8 \%, P=0.59$; Table 2). Among HIV-positive women, HPV prevalence did not decrease with increasing age $(P=0.898)$. 
HPV prevalence was $36.7 \%(76 / 207 ; 95 \%$ CI: 30.4-43.5 \%) in HIV-negative women, with the highest prevalence of $61.0 \%(25 / 41 ; 95 \%$ CI: $45.7-$ $74.4 \%$ ) in women $18-25$ years of age and lowest prevalence of $23.8 \%(15 / 63$; $95 \%$ CI: $14.9-35.7 \%)$ in women 36-45 years of age. HPV prevalence was found to be significantly higher in age group 18-25 years compared to 26-35 years $(61.0 \%$ compared to $39.0 \%, P=0.03)$; to $36-45$ years $(61.0 \%$ compared to $23.8 \%, P=0.0002)$ and to $46-66$ years $(61.0 \%$ compared to $29.5 \%, P=0.004$; Table 2 ). HPV prevalence was found to decrease with increasing age in HIV-negative women $(P=0.0007)$. HIV-positive women were found to have significantly higher HPV prevalence compared to HIVnegative women in all age group (Table 2).

A higher proportion of detected HPV types in multiple infections than single infection were observed. The distribution of multiple infections (range: 2-14 HPV genotypes) is shown in Fig. 1a for HIV-positive women and Fig. 1b for HIV-negative women. Multiple HPV infections in HIV-negative women were more likely to be 2 HPV types while in HIV-positive women the distribution of multiple HPV types spread up over $\geq 5$ HPV types.
HPV prevalence in men according to age and HIV status Table 3 presents prevalence of any HPV, HR-HPV, probable HR-HPV, LR-HPV, multiple HPV infection and single HPV infection stratified by age and HIV status in men. HPV prevalence in men was 59.4 \% (280/471; $95 \%$ CI: $55.0-63.8 \%)$ with the highest prevalence of $79.1 \%$ (34/43; 95 \% CI: 64.6-88.8\%) in men 18-25 years of age and lowest prevalence of $47.6 \%$ (50/105; $95 \%$ CI: 38.3-57.1 \%) in age. HPV prevalence was found to be significantly higher in age group 18-25 years compared to $26-35$ years $(79.1 \%$ compared to $60.9 \%, P=0.03)$; to $36-45$ years $(79.1 \%$ compared to $60.5 \%, P=0.02)$ and to 46-66 years (79.1\% compared to $47.9 \%, P=0.0005)$. HPV prevalence was found to decrease with increasing age in men $(P=0.0012)$. The prevalence of multiple infections was $41.0 \%(193 / 471)$ and of single infection was $18.5 \%(87 / 471)$ in men.

HPV prevalence was 76.6 \% (121/158; 95 \% CI: 69.4$82.5 \%)$ in HIV-positive men, with the highest prevalence of $87.5 \%$ (7/8; $95 \%$ CI: $50.8-99.9 \%)$ in men $18-25$ years of age and lowest prevalence of $71.4 \%(15 / 21$; 95 \% CI: 49.8-86.4 \%) in men 46-66 years of age. HPV prevalence was not found to be significantly higher in

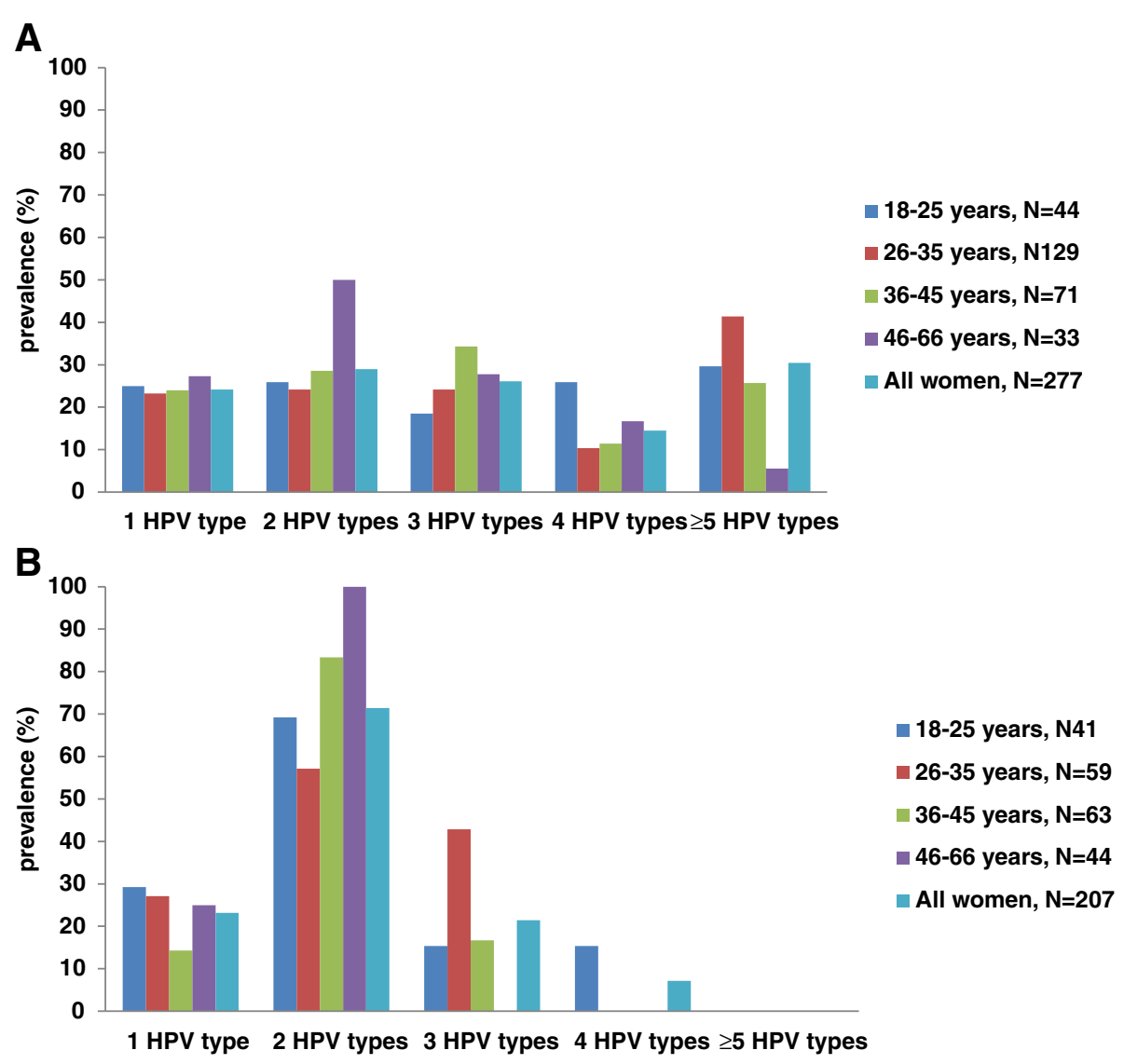

Fig. 1 Distribution of multiple HPV genotype infections in HIV-positive (a) and HIV-negative (b) women 
Table 3 Human papillomavirus (HPV) by age and human immunodeficiency (HIV) status in men

\begin{tabular}{|c|c|c|c|c|}
\hline & All men & HIV-positive men & HIV-negative men & $P$-value ${ }^{a}$ \\
\hline & $N=471$ & $N=158$ & $N=313$ & \\
\hline Any HPV & & & & \\
\hline All men & $59.4 \%(280 / 471)$ & $76.6 \%(121 / 158)$ & $50.8 \%(159 / 313)$ & $<0.0001$ \\
\hline $18-25$ years & $79.1 \%(34 / 43)$ & $87.5 \%(7 / 8)$ & $77.1 \%(27 / 35)$ & 0.535 \\
\hline $26-35$ years & $60.9 \%(95 / 156)$ & $77.8 \%(49 / 63)$ & $49.5 \%(46 / 93)$ & 0.0004 \\
\hline $36-45$ years & $60.5 \%(101 / 167)$ & $75.8 \%(50 / 66)$ & $50.5 \%(51 / 101)$ & 0.001 \\
\hline $46-66$ years & $47.6 \%(50 / 105)$ & $71.4 \%(15 / 21)$ & $41.7 \%(35 / 84)$ & 0.015 \\
\hline Multiple HPV infec & & & & \\
\hline All men & $41.0 \%(193 / 471)$ & $62.7 \%(99 / 158)$ & $30.0 \%(94 / 313)$ & $<0.0001$ \\
\hline $18-25$ years & $55.8 \%(24 / 43)$ & $87.5 \%(7 / 8)$ & $48.6 \%(17 / 35)$ & 0.050 \\
\hline $26-35$ years & $44.2 \%(69 / 156)$ & $68.3 \%(43 / 63)$ & $28.0 \%(26 / 93)$ & $<0.0001$ \\
\hline $36-45$ years & $41.3 \%(69 / 167)$ & $59.1 \%(39 / 66)$ & $29.7 \%(30 / 101)$ & 0.0002 \\
\hline $46-66$ years & $29.5 \%(31 / 105)$ & $47.6 \%(10 / 21)$ & $25.0 \%(21 / 84)$ & 0.041 \\
\hline Single HPV infecti & & & & \\
\hline All men & $18.5 \%(87 / 471)$ & $13.9 \%(22 / 158)$ & $20.8 \%(65 / 313)$ & 0.071 \\
\hline $18-25$ years & $23.3 \%(10 / 43)$ & $0.0 \%(0 / 8)$ & $28.6 \%(10 / 35)$ & $\ldots$ \\
\hline $26-35$ years & $35.9 \%(56 / 156)$ & $9.5 \%(6 / 63)$ & $21.5 \%(20 / 93)$ & 0.050 \\
\hline $36-45$ years & $19.2 \%(32 / 167)$ & $16.7 \%(11 / 66)$ & $20.8 \%(21 / 101)$ & 0.511 \\
\hline $46-66$ years & $18.1 \%(19 / 105)$ & $23.8 \%(5 / 21)$ & $16.7 \%(14 / 84)$ & 0.453 \\
\hline HR-HPV & & & & \\
\hline All men & $19.7 \%(93 / 471)$ & $54.4 \%(86 / 158)$ & $22.4 \%(70 / 313)$ & $<0.0001$ \\
\hline $18-25$ years & $48.8 \%(21 / 43)$ & $75.0 \%(6 / 8)$ & $42.9 \%(15 / 35)$ & 0.109 \\
\hline $26-35$ years & $39.1 \%(61 / 156)$ & $61.9 \%(39 / 63)$ & $23.7 \%(22 / 93)$ & $<0.0001$ \\
\hline $36-45$ years & $32.9 \%(55 / 167)$ & $50.0 \%(33 / 66)$ & $21.8 \%(22 / 101)$ & 0.0002 \\
\hline $46-66$ years & $21.0 \%(22 / 105)$ & $28.6 \%(6 / 21)$ & $19.0 \%(16 / 84)$ & 0.343 \\
\hline Probable HR-HPV & & & & \\
\hline All men & $16.1 \%(76 / 471)$ & $54.4 \%(86 / 158)$ & $20.8 \%(65 / 313)$ & $<0.0001$ \\
\hline $18-25$ years & $41.9 \%(18 / 43)$ & $62.5 \%(5 / 8)$ & $37.1 \%(13 / 35)$ & 0.201 \\
\hline $26-35$ years & $28.2 \%(44 / 156)$ & $44.4 \%(28 / 63)$ & $17.2 \%(16 / 93)$ & 0.0002 \\
\hline $36-45$ years & $29.9 \%(50 / 167)$ & $31.8 \%(21 / 66)$ & $28.7 \%(29 / 101)$ & 0.671 \\
\hline 46-66 years & $15.2 \%(16 / 105)$ & $42.9 \%(9 / 21)$ & $8.3 \%(7 / 84)$ & $<0.0001$ \\
\hline LR-HPV & & & & \\
\hline All men & $29.5 \%(139 / 471)$ & $63.9 \%(101 / 158)$ & $33.2 \%(104 / 313)$ & $<0.0001$ \\
\hline $18-25$ years & $53.5 \%(23 / 43)$ & $75.0 \%(6 / 8)$ & $48.6 \%(17 / 35)$ & 0.187 \\
\hline $26-35$ years & $37.8 \%(59 / 156)$ & $66.7 \%(42 / 63)$ & $18.3 \%(17 / 93)$ & $<0.0001$ \\
\hline $36-45$ years & $47.9 \%(80 / 167)$ & $59.1 \%(39 / 66)$ & $40.6 \%(41 / 101)$ & 0.020 \\
\hline $46-66$ years & $41.0 \%(43 / 105)$ & $66.7 \%(14 / 21)$ & $34.5 \%(29 / 84)$ & 0.008 \\
\hline
\end{tabular}

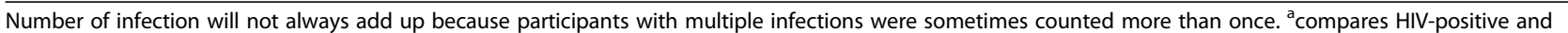
HIV-negative men (chi-squared test)

age group 18-25 years compared to $26-35$ years $(87.5 \%$ compared to $77.8 \%, P=0.54)$; to $36-45$ years $(87.5 \%$ compared to $75.8 \%, P=0.47)$ and to $46-66$ years (87.5 \% compared to $71.4 \%, P=0.39$ ). HPV prevalence was not found to decrease with increasing age in HIVpositive men $(P=0.385)$; however, overall HPV prevalence and prevalence of multiple infections were high across all age groups (Table 3 ).

HPV prevalence was 50.8\% (159/313; $95 \%$ CI: 45.3-56.3 \%) in HIV-negative men, with the highest prevalence of $77.1 \%$ (27/35; $95 \%$ CI: 60.7-88.2 \%) in men 18-25 years of age and lowest prevalence of $41.7 \%$ 
(35/84; 95 \% CI: 31.7-52.4\%) in men 46-66 years of age. HPV prevalence was found to be significantly higher in age group 18-25 years compared to 26-35 years $(77.1 \%$ compared to $49.5 \%, P=0.005)$; to $36-45$ years $(77.1 \%$ compared to $50.5 \%, P=0.006)$ and to $46-66$ years $(77.1 \%$ compared to $41.7 \%, P=0.0004)$. HPV prevalence was found to decrease with increasing age in HIV-negative men $(P=0.004)$. HIV-positive men were found to have significantly higher HPV prevalence compared to HIV-negative men in all age groups except for 18-25 years age group (Table 3 ).

A higher proportion of detected HPV types were observed in multiple infections than single infection. The distribution of multiple infections (range: 2-13 HPV genotypes) is shown in Fig. 2a for HIV-positive men and Fig. 2b for HIV-negative men. Multiple HPV infections in HIV-negative men were more likely to be $2 \mathrm{HPV}$ types while in HIV-positive men the distribution of multiple HPV types spread up to $\geq 5$ HPV types.

\section{Prevalence of HPV types targeted by current HPV vaccines}

HIV-positive women had a significantly higher prevalence of one or more HPV types found in the bivalent vaccine (HPV-16/18: $20 \%$ 55/277, $9 \%$ 12/207; $P<0.001$ ), in the quadrivalent vaccine (HPV-6/11/16/18: $26 \% 71 / 277,12 \%$ $24 / 207 ; P=0.001$ ) and in the nonavalent vaccine (HPV-6/ 11/16/18/31/33/52/56/58: 65 \% 181/277, $24 \%$ 50/207; $P<0.001)$ compared to HIV-negative women (Fig. 3). HIV-positive men also had a significantly higher prevalence of one or more types found in the bivalent vaccine (20\% 32/158, $10 \% 30 / 313 ; P=0.001)$, in the quadrivalent vaccine (35 \% 56/158, $13 \% 41 / 313 ; P<0.001)$ and in the nonavalent vaccine (75 \% 119/158, $28 \%$ 87/313; $P<0.001)$ compared to HIV-negative men (Fig. 3).

\section{Discussion}

We previously reported the influence of HIV co-infection on HPV prevalence, acquisition and clearance in women

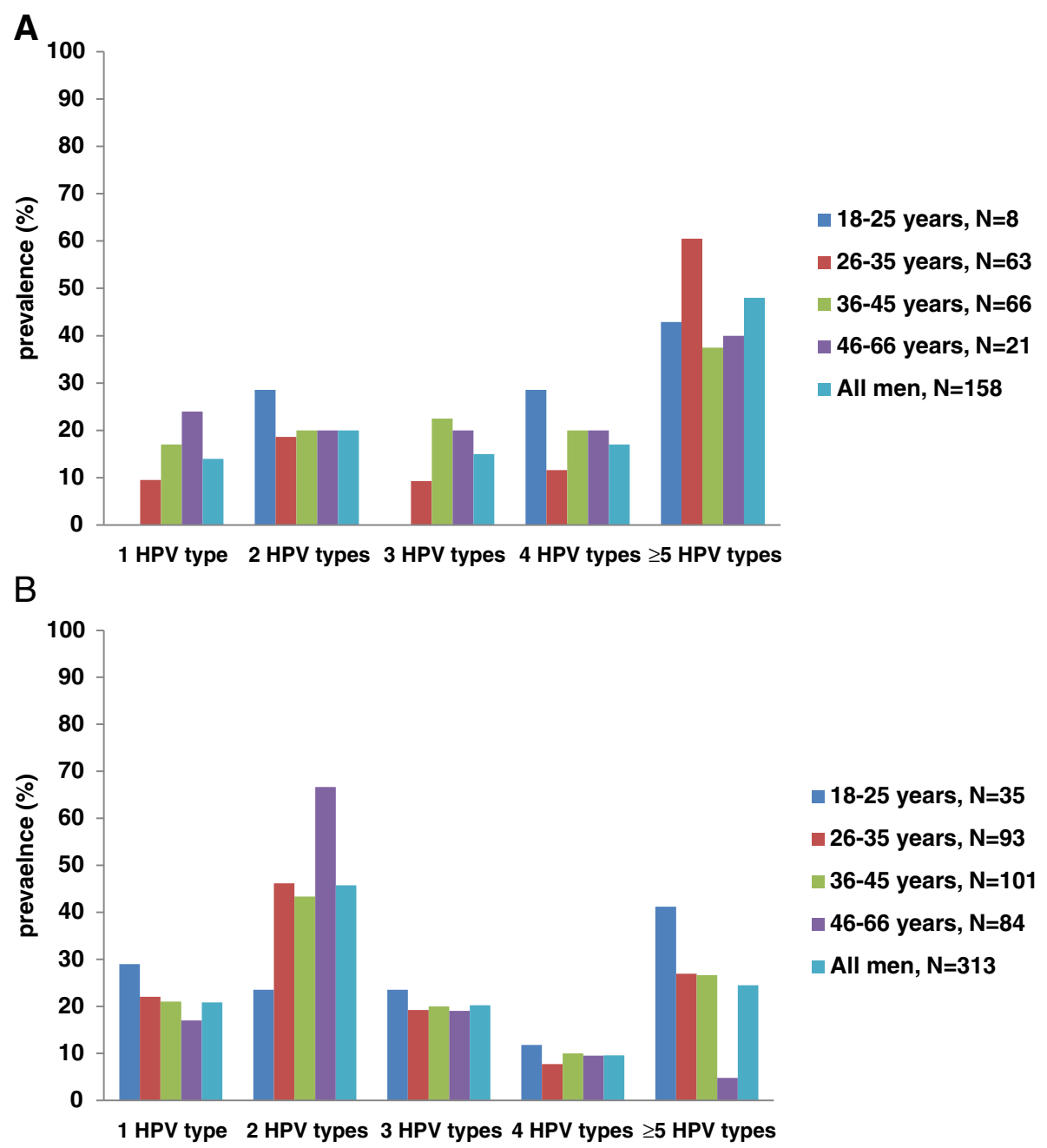

Fig. 2 Distribution of multiple HPV genotype infections in HIV-positive (a) and HIV-negative (b) men 


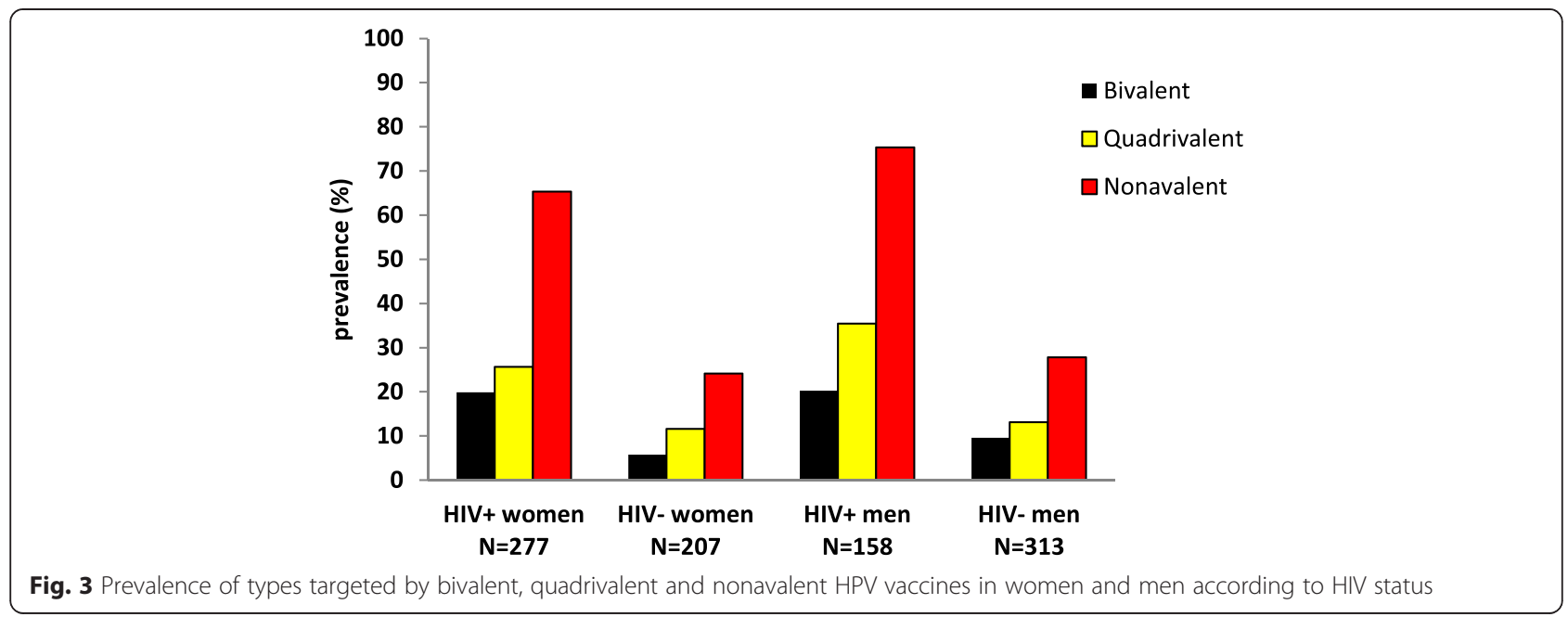

and men $[13,43,45,46]$ and HPV concordance and transmission in sexual active couples [43, 46, 47]. The current report further demonstrates prevalence of any HPV type, LR-HPV, probable HR-HPV, LR-HPV, multiple HPV infections, single HPV infection and prevalence of HPV types targeted by bivalent, quadrivalent and nonavalent vaccines in women and men according to HIV status and age. HPV prevalence data specified by age and HIV status is important in understanding HPV trends especially in a country where HIV prevalence is very high. Women and men participated in this study were recruited as couples from the same community, a community with high prevalence of HIV ( $30 \%$ amongst pregnant women) and sexually transmitted infections [48, 49].

Higher prevalence of any HPV type, multiple infections, and types targeted by bivalent, quadrivalent and nonavalent vaccines in HIV-positives compared to HIVnegatives were observed. Generally, in women HPV prevalence decreased with age and this has been reported elsewhere $[9,38,50-52]$. However, when grouped according to HIV-status HPV prevalence decreased with age among HIV-negatives but not among HIV-positive women. In South African studies, HPV prevalence has also decreased with increasing age in HIV-negative women $[53,54]$ and in women not stratified by HIV status [55]. Notably in this study overall HPV prevalence and multiple infection prevalence remained high in HIVpositive women across all age groups while it decreased with age among HIV-negative women. McDonald et al., reported higher a HPV prevalence in South African among HIV-positive women compared to HIV-negative women in all age groups [54].

The higher prevalence of HPV in older HIV-positive women could be due to high rate of HPV reactivation as a result of suppressed immune system and susceptibility to new infections in HIV-positive women $[17,19]$. According to Kjaer et al., HPV prevalence declines with age, even in highly sexually active women such as sex workers [52]. Some have suggested that older HIVpositive women are more likely to fail to clear the HPV infection they acquired at a young age or later, due to immune senescence [56, 57]. This is important as the persistence of genital HPV infection is associated with cervical disease progression [58]. A more intensive cervical screening program is required due to the high HPV prevalence and multiple infections across all age group among HIV-positive women.

HIV-prevalence was found to decrease with increasing age in men, when grouped according to HIV-status, this was also observed in HIV-negative men but not among HIV-positive men. In contrast, HPV prevalence in men has been reported not to vary with age [41, 42], however these reports were not reported according to HIV status. High HPV prevalence across age groups or slightly decrease as the age increases suggest high rate of persistent and acquired new HPV infections [42]. We previously reported high persistent and acquired new infection during follow-up among HIV-positive women and men in this cohort [13].

A high prevalence of infections with multiple HPV types was observed in HIV-positive women and men. HPV multiple infections are associated with a higher rate of persistent HPV infection than single infection [59]. Munagala et al., showed that persons with infections with multiple HPV types were more likely to have larger tumor and a poorer response to cancer treatment when compared with participants with single HPV infection [60]. HPV persistent infection is associated with the development of HPV related cancers in both women and men; while multiple HPV infection seem to complicate the response to treatment; and cancer prevention and treatment programs need to take this into consideration [59, 61]. The observations that single infection were more likely to be HR-HPV types than LR-HPV in 
women and not in men could be due to the fact that in women only the cervix was sampled. Jones et al., showed that LR-HPV were more likely to reside in the vagina than in the cervix [62]. In men several sites (penile shaft, glans and foreskin if uncircumcised) were sampled [43].

The prevalence of HPV types targeted by bivalence, quadrivalent and nonavalent HPV vaccines were found to be significantly higher among HIV-positives than HIV-negatives. Giuliano et al., reported a similar prevalence of one or more HPV types in quadrivalent (20\%) and nonavalent $(28 \%)$ vaccines in South African HIVnegative women [53].

The study was limited by the small sample size. Due to the small sample size the impact of HIV viral load and CD4 counts on HPV prevalence could not be stratified by age. All participants recruited for the study were volunteers and therefore not representative of the general population. Only participants who were sexually active were included and this was based on having had sexual intercourse in the previous month with a partner of the opposite sex and this was subject to recall bias. As this was a cross-sectional study a time sequence could not be interred.

\section{Conclusion}

This study demonstrated high prevalence of HPV and multiple HPV infection among HIV-positive women compared to HIV-negative women across all ages. Older HIV-negative men had a higher prevalence of HPV compared to HIV-negative women of the same age group. The high prevalence of HPV types targeted by bivalent, quadrivalent and nonavalent vaccines in South African HIV-positive and HIV-negative women and men demonstrate that this population will greatly benefit from current HPV vaccines. Studies on HPV prevalence should be stratified by age and HIV status in both women and men.

\section{Abbreviations}

Cl: Confident interval; HIV: Human immunodeficiency virus; HPV: Human papillomavirus; HR: High-risk; LR: Low-risk.

\section{Competing interests}

The authors declare that they have no competing interest.

\section{Authors' contributions}

DC and ALW were responsible for study set-up and specimen collection. ZZAM was responsible for specimen storage and HPV genotyping. Data analysis was performed by DC and ZZAM. The first draft was written by ZZAM, with contributions from DC and ALW. All authors were actively involved in the interpretation of the data, creation and revision of the manuscript; and approval of the final manuscript.

\section{Acknowledgements}

We thank the Bruce Allan, Nobuntu Noveve, staff (Nozizwe Makola, Zonke Makhonza, Monde Mtyoko, Tembisa Nkompela, Zukiswa Mazula, Mkhanyiseli Mpalali, Khunjuzwa Khume, Pamela Magona, Sindiswa Godwana, Khayalethu Tshangela and Thokozile Tshangela) at Empilisweni centre and the study participants.

\section{Funding}

The present study was funded by Poliomyelitis Research Fund, Medical Research Council, Swedish International Development Cooperation Agency, Swedish Cancer Foundation, Cancer Association of South Africa and National Health Laboratory Services. This work was also partially based upon research supported by the South African Research Chairs Initiative of the Department of Science and Technology and National Research Foundation. Initial recruitment of couples who participated in this study was funded by the Bill and Melinda Gates Foundation. Participants were recruited for a study funded by the Bill and Melinda Gates Foundation.

\section{Author details}

${ }^{1}$ Institute of Infectious Disease and Molecular Medicine and Division of Medical Virology, University of Cape Town, Anzio Road, Observatory, 7925 Cape Town, South Africa. ${ }^{2}$ Center for HIV and STIs, National Institute for Communicable Disease, National Health Laboratory Service, Cape Town, South Africa. ${ }^{3}$ Centre for Infectious Disease Epidemiology and Research, School of Public Health and Family Medicine, University of Cape Town, Cape Town, South Africa. ${ }^{4}$ SAMRC Gynaecological Cancer Centre, University of Cape Town, Cape Town, South Africa. ${ }^{5}$ National Health Laboratory Service, Groote Schuur Hospital, Observatory, Cape Town 7925, South Africa.

Received: 20 March 2015 Accepted: 6 October 2015

Published online: 26 October 2015

\section{References}

1. UNAIDS's push to end epidemic. Science. 2014;346(6213):1036.

2. Who U, Unicef. Global report: UNAIDS report on the global AIDS epidemic 2013. Geneva: UNAIDS; 2013.

3. Naicker N, Kharsany AB, Werner L, van Loggerenberg F, Mlisana K, Garrett N, et al. Risk factors for HIV acquisition in high risk women in a generalised epidemic setting. AIDS Behav. 2015;19(7):1305-16.

4. MacPhail C, Williams BG, Campbell C. Relative risk of HIV infection among young men and women in a South African township. Int J STD AIDS. 2002;13(5):331-42.

5. Kelly RJ, Gray RH, Sewankambo NK, Serwadda D, Wabwire-Mangen F, Lutalo $T$, et al. Age differences in sexual partners and risk of HIV-1 infection in rural Uganda. J Acquir Immune Defic Syndr. 2003;32(4):446-51.

6. Pettifor AE, Rees HV, Kleinschmidt I, Steffenson AE, MacPhail C, HlongwaMadikizela L, et al. Young people's sexual health in South Africa: HIV prevalence and sexual behaviors from a nationally representative household survey. Aids. 2005;19(14):1525-34.

7. Jewkes R, Dunkle K, Nduna M, Levin J, Jama N, Khuzwayo N, et al. Factors associated with HIV sero-status in young rural South African women: connections between intimate partner violence and HIV. Int J Epidemiol. 2006;35(6):1461-8.

8. McGrath N, Nyirenda M, Hosegood V, Newell ML. Age at first sex in rural South Africa. Sex Transm Infect. 2009;85 Suppl 1:i49-55.

9. de Sanjose S, Diaz M, Castellsague X, Clifford G, Bruni L, Munoz N, et al. Worldwide prevalence and genotype distribution of cervical human papillomavirus DNA in women with normal cytology: a meta-analysis. Lancet Infect Dis. 2007;7(7):453-9.

10. Vinodhini K, Shanmughapriya S, Das BC, Natarajaseenivasan K. Prevalence and risk factors of HPV infection among women from various provinces of the world. Arch Gynecol Obstet. 2012;285(3):771-7.

11. Ferlay J, Shin HR, Bray F, Forman D, Mathers C, Parkin DM. Estimates of worldwide burden of cancer in 2008: GLOBOCAN 2008. Int J Cancer. 2010;127(12):2893-917.

12. Lissouba $P$, Van de Perre $P$, Auvert B. Association of genital human papillomavirus infection with HIV acquisition: a systematic review and metaanalysis. Sex Transm Infect. 2013;89(5):350-6.

13. Mbulawa ZZ, Marais DJ, Johnson LF, Coetzee D, Williamson AL. Impact of human immunodeficiency virus on the natural history of human papillomavirus genital infection in South African men and women. J Infect Dis. 2012;206(1):15-27.

14. Smits PH, Bakker R, Jong E, Mulder JW, Meenhorst PL, Kleter B, et al. High prevalence of human papillomavirus infections in urine samples from human immunodeficiency virus-infected men. J Clin Microbiol. 2005;43(12):5936-9.

15. Heard I, Tassie JM, Schmitz V, Mandelbrot L, Kazatchkine MD, Orth G Increased risk of cervical disease among human immunodeficiency virus-infected women with severe immunosuppression and high human papillomavirus load(1). Obstet Gynecol. 2000;96(3):403-9. 
16. Riva E, Serraino D, Pierangeli A, Bambacioni F, Zaniratti S, Minosse C, et al. Markers of human papillomavirus infection and their correlation with cervical dysplasia in human immunodeficiency virus-positive women. Clin Microbiol Infect. 2007;13(1):94-7.

17. Levi JE, Fernandes S, Tateno AF, Motta E, Lima LP, Eluf-Neto J, et al. Presence of multiple human papillomavirus types in cervical samples from HIV-infected women. Gynecol Oncol. 2004;92(1):225-31.

18. Levi JE, Kleter B, Quint WG, Fink MC, Canto CL, Matsubara R, et al. High prevalence of human papillomavirus (HPV) infections and high frequency of multiple HPV genotypes in human immunodeficiency virus-infected women in Brazil. J Clin Microbiol. 2002;40(9):3341-5.

19. Strickler HD, Burk RD, Fazzari M, Anastos K, Minkoff H, Massad LS, et al. Natural history and possible reactivation of human papillomavirus in human immunodeficiency virus-positive women. J Natl Cancer Inst. 2005;97(8):577-86.

20. Lomalisa P, Smith T, Guidozzi F. Human immunodeficiency virus infection and invasive cervical cancer in South Africa. Gynecol Oncol. 2000;77(3):460-3.

21. Frisch M, Biggar RJ, Goedert JJ. Human papillomavirus-associated cancers in patients with human immunodeficiency virus infection and acquired immunodeficiency syndrome. J Natl Cancer Inst. 2000;92(18):1500-10.

22. Chin-Hong PV, Husnik M, Cranston RD, Colfax G, Buchbinder S, Da Costa M, et al. Anal human papillomavirus infection is associated with HIV acquisition in men who have sex with men. Aids. 2009;23(9):1135-42.

23. Auvert B, Lissouba P, Cutler E, Zarca K, Puren A, Taljaard D. Association of oncogenic and nononcogenic human papillomavirus with HIV incidence. J Acquir Immune Defic Syndr. 2010;53(1):111-6.

24. Auvert B, Sobngwi-Tambekou J, Cutler E, Nieuwoudt M, Lissouba P, Puren A, et al. Effect of male circumcision on the prevalence of high-risk human papillomavirus in young men: results of a randomized controlled trial conducted in Orange Farm, South Africa. J Infect Dis. 2009;199(1):14-9.

25. Smith JS, Moses S, Hudgens MG, Parker CB, Agot K, Maclean I, et al. Increased risk of HIV acquisition among Kenyan men with human papillomavirus infection. J Infect Dis. 2010;201(11):1677-85.

26. Smith-McCune KK, Shiboski S, Chirenje MZ, Magure T, Tuveson J, Ma Y, et al. Type-specific cervico-vaginal human papillomavirus infection increases risk of HIV acquisition independent of other sexually transmitted infections. PLoS One. 2010;5(4):e10094.

27. Averbach SH, Gravitt PE, Nowak RG, Celentano DD, Dunbar MS, Morrison CS, et al. The association between cervical human papillomavirus infection and HIV acquisition among women in Zimbabwe. Aids. 2010;24(7):1035-42.

28. Veldhuijzen NJ, Vyankandondera J, van de Wijgert JH. HIV acquisition is associated with prior high-risk human papillomavirus infection among high-risk women in Rwanda. Aids. 2010;24(14):2289-92.

29. Houlihan CF, Larke NL, Watson-Jones D, Smith-McCune KK, Shiboski S, Gravitt PE, et al. Human papillomavirus infection and increased risk of HIV acquisition. A systematic review and meta-analysis. Aids. 2012;26(17):2211-22.

30. Rositch AF, Gravitt PE, Smith JS. Growing evidence that HPV infection is associated with an increase in HIV acquisition: exploring the issue of HPV vaccination. Sex Transm Infect. 2013;89(5):357.

31. Joura EA, Giuliano AR, Iversen OE, Bouchard C, Mao C, Mehlsen J, et al. A 9valent HPV vaccine against infection and intraepithelial neoplasia in women. N Engl J Med. 2015;372(8):711-23.

32. Joura EA, Leodolter $S$, Hernandez-Avila M, Wheeler CM, Perez G, Koutsky LA, et al. Efficacy of a quadrivalent prophylactic human papillomavirus (types 6, 11, 16, and 18) L1 virus-like-particle vaccine against high-grade vulval and vaginal lesions: a combined analysis of three randomised clinical trials. Lancet. 2007;369(9574):1693-702.

33. Garland SM, Hernandez-Avila M, Wheeler CM, Perez G, Harper DM, Leodolter $S$, et al. Quadrivalent vaccine against human papillomavirus to prevent anogenital diseases. N Engl J Med. 2007;356(19):1928-43.

34. Paavonen J, Naud P, Salmeron J, Wheeler CM, Chow SN, Apter D, et al. Efficacy of human papillomavirus (HPV)-16/18 AS04-adjuvanted vaccine against cervical infection and precancer caused by oncogenic HPV types (PATRICIA): final analysis of a double-blind, randomised study in young women. Lancet. 2009;374(9686):301-14.

35. Palefsky JM, Giuliano AR, Goldstone S, Moreira Jr ED, Aranda C, Jessen H, et al. HPV vaccine against anal HPV infection and anal intraepithelial neoplasia. N Engl J Med. 2011;365(17):1576-85.

36. Giuliano AR, Palefsky JM, Goldstone S, Moreira Jr ED, Penny ME, Aranda C, et al. Efficacy of quadrivalent HPV vaccine against HPV Infection and disease in males. N Engl J Med. 2011;364(5):401-11.
37. Tiggelaar SM, Lin MJ, Viscidi RP, Ji J, Smith JS. Age-specific human papillomavirus antibody and deoxyribonucleic acid prevalence: a global review. J Adolesc Health. 2012;50(2):110-31.

38. Smith JS, Melendy A, Rana RK, Pimenta JM. Age-specific prevalence of infection with human papillomavirus in females: a global review. J Adolesc Health. 2008:43(4 Suppl):S5-25. S25.e21-41.

39. Olesen TB, Iftner T, Mwaiselage J, Kahesa C, Rasch V, Ngoma T, et al. Prevalence and type distribution of human papillomavirus among 1813 men in Tanzania and the relationship to HIV status. Sex Transm Dis. 2013;40(7):592-8.

40. Olesen TB, Munk C, Christensen J, Andersen KK, Kjaer SK. Human papillomavirus prevalence among men in sub-Saharan Africa: a systematic review and meta-analysis. Sex Transm Infect. 2014;90(6):455-62.

41. Giuliano AR, Lazcano-Ponce E, Villa LL, Flores R, Salmeron J, Lee JH, et al. The human papillomavirus infection in men study: human papillomavirus prevalence and type distribution among men residing in Brazil, Mexico, and the United States. Cancer Epidemiol Biomark Prev. 2008;17(8):2036-43.

42. Smith JS, Gilbert PA, Melendy A, Rana RK, Pimenta JM. Age-specific prevalence of human papillomavirus infection in males: a global review. J Adolesc Health. 2011;48(6):540-52.

43. Mbulawa ZZ, Coetzee D, Marais DJ, Kamupira M, Zwane E, Allan B, et al. Genital human papillomavirus prevalence and human papillomavirus concordance in heterosexual couples are positively associated with human immunodeficiency virus coinfection. J Infect Dis. 2009;199(10):1514-24.

44. Bouvard V, Baan R, Straif K, Grosse Y, Secretan B, El Ghissassi F, et al. A review of human carcinogens_-Part B: biological agents. Lancet Oncol. 2009;10(4):321-2

45. Mbulawa ZZ, Johnson LF, Marais DJ, Gustavsson I, Moodley JR, Coetzee D, et al. Increased alpha-9 human papillomavirus species viral load in human immunodeficiency virus positive women. BMC Infect Dis. 2014;14:51.

46. Mbulawa ZZ, Marais DJ, Johnson LF, Boulle A, Coetzee D, Williamson AL. Influence of human immunodeficiency virus and CD4 count on the prevalence of human papillomavirus in heterosexual couples. J Gen Virol. 2010;91(Pt 12):3023-31

47. Mbulawa ZZ, Johnson LF, Marais DJ, Coetzee D, Williamson AL. The impact of human immunodeficiency virus on human papillomavirus transmission in heterosexually active couples. J Infect. 2013;67(1):51-8.

48. Simbayi L, Shisana O, Rehle T, Onoya D, Jooste S, Zungu N, et al. South African national HIV prevalence, incidence and behaviour survey, 2012. Pretoria: Human Sciences Research Council; 2014.

49. Myer L, Phillips T, Manuelli V, McIntyre J, Bekker LG, Abrams EJ. Evolution of antiretroviral therapy services for HIV-infected pregnant women in Cape Town, South Africa. J Acquir Immune Defic Syndr. 2015. [Epub ahead of print].

50. Forman D, de Martel C, Lacey CJ, Soerjomataram I, Lortet-Tieulent J, Bruni L, et al. Global burden of human papillomavirus and related diseases. Vaccine. 2012;30 Suppl 5:F12-23.

51. Cuschieri KS, Cubie HA, Whitley MW, Seagar AL, Arends MJ, Moore C, et al. Multiple high risk HPV infections are common in cervical neoplasia and young women in a cervical screening population. J Clin Pathol. 2004;57(1):68-72.

52. Kjaer SK, Svare El, Worm AM, Walboomers JM, Meijer CJ, van den Brule AJ. Human papillomavirus infection in Danish female sex workers. Decreasing prevalence with age despite continuously high sexual activity. Sex Transm Dis. 2000;27(8):438-45.

53. Giuliano AR, Botha MH, Zeier M, Abrahamsen ME, Glashoff $\mathrm{RH}$, van der Laan LE, et al. High HIV, HPV, and STI prevalence among Young Western Cape, South African Women: EVRI HIV prevention preparedness trial. J Acquir Immune Defic Syndr. 2015;68(2):227-35.

54. McDonald AC, Tergas Al, Kuhn L, Denny L, Wright Jr TC. Distribution of Human Papillomavirus genotypes among HIV-positive and HIV-negative Women in Cape Town, South Africa. Front Oncol. 2014;4:48.

55. Richter K, Becker P, Horton A, Dreyer G. Age-specific prevalence of cervical human papillomavirus infection and cytological abnormalities in women in Gauteng Province, South Africa. S Afr Med J. 2013;103(5):313-7.

56. Giuliano AR, Harris R, Sedjo RL, Baldwin S, Roe D, Papenfuss MR, et al. Incidence, prevalence, and clearance of type-specific human papillomavirus infections: The Young Women's Health Study. J Infect Dis. 2002;186(4):462-9.

57. Andersson S, Safari H, Mints M, Lewensohn-Fuchs I, Gyllensten U, Johansson B. Type distribution, viral load and integration status of high-risk human papillomaviruses in pre-stages of cervical cancer (CIN). Br J Cancer. 2005;92(12):2195-200. 
58. Munoz N, Castellsague X, de Gonzalez AB, Gissmann L. Chapter 1: HPV in the etiology of human cancer. Vaccine. 2006;24 Suppl 3:S3/1-10.

59. Trottier H, Mahmud S, Prado JC, Sobrinho JS, Costa MC, Rohan TE, et al. Type-specific duration of human papillomavirus infection: implications for human papillomavirus screening and vaccination. J Infect Dis. 2008:197(10):1436-47.

60. Munagala R, Dona MG, Rai SN, Jenson AB, Bala N, Ghim SJ, et al. Significance of multiple HPV infection in cervical cancer patients and its impact on treatment response. Int J Oncol. 2009;34(1):263-71.

61. Bello BD, Spinillo A, Alberizzi P, Cesari S, Gardella B, D'Ambrosio G, et al. Cervical infections by multiple human papillomavirus (HPV) genotypes: prevalence and impact on the risk of precancerous epithelial lesions. J Med Virol. 2009:81 (4):703-12.

62. Jones HE, Allan BR, van de Wijgert JH, Altini L, Taylor SM, de Kock A, et al. Agreement between self- and clinician-collected specimen results for detection and typing of high-risk human papillomavirus in specimens from women in Gugulethu, South Africa. J Clin Microbiol. 2007;45(6):1679-83.

\section{Submit your next manuscript to BioMed Central and take full advantage of:}

- Convenient online submission

- Thorough peer review

- No space constraints or color figure charges

- Immediate publication on acceptance

- Inclusion in PubMed, CAS, Scopus and Google Scholar

- Research which is freely available for redistribution 